\title{
Biomonitoring tool: Morphological anomalies in Zygnema sp. of Ganga river bank
}

\author{
Koushiki Das ${ }^{1}$, Kaushik Gupta ${ }^{1}$, Snehasikta Swarnakar², \\ Soumendra Nath Talapatra ${ }^{1^{*}}$ \\ ${ }^{1}$ Career Advancement Solutions \\ $\mathrm{H} 2$ - 120A/ New Bener Pole Road \\ Maheshtala, Kolkata - 700141, India \\ ${ }^{2}$ CSIR-Indian Institute of Chemical Biology \\ Division of Cancer Biology \& Inflammatory Disorder \\ 4, Raja S. C. Mallick Road, Jadvapur, \\ Kolkata - 700032, India
}

\begin{abstract}
${ }^{*}$ Corresponding author: Dr. Soumendra Nath Talapatra, Chief Scientist, H2 - 120A, New Bener Pole Road, Kolkata 700141. phone: +919831008689, email: ecologylive@yahoo.co.in
\end{abstract}

Keywords: Biomonitoring, morphological alteration, algae species, ecosystem, river

\begin{abstract}
The present study aims to detect morphological abnormalities in Zygnema sp. because this test species have high adaptive capacity in unfavourable environmental stress. This alga is inhabited at the suburban bank of river Ganga, West Bengal, India. The study was done at experimental sites, downstream at Khardah near sewage water mixing area was compared with upstream control site Kalyani as no sewage water discharge. External and internal abnormal morphology such as undulating or wavy and extra outgrowth on cell wall, sometimes bending inwardly and outwardly as external deformities while internal anomalies such as pigment loss, nucleus was in circular, rectangular, oval and amoeboid shapes, also vacuolated and trilobed, broom like chloroplasts and central part of the thallas dried in between two segments. It was observed that this test species was surviving and well adapted with above mentioned deformities. The present preliminary study with Zygnema sp. can be utilized for in situ and ex situ indicator species for riverine biomonitoring. Further research may be relevant to know both tolerant and sensitive algae species inhabited at the river Ganga bank alongwith biochemical and genetic parameters. The present work is suggesting that other inhabiting algae and this adaptive test species can be used for bioremediation of pollutants.
\end{abstract}

\section{INTRODUCTION}

Biomonitoring with special reference to morphological abnormalities in algae is a suitable tool to detect water quality for aquatic ecosystem (Singh and Rai, 1990; Pandey et al., 2014). It was previously established that water pollution monitoring by analysis of physico-chemical properties of particular waterbodies especially in lotic ecosystem (Agarwal et al., 1976; Mitra, 1982; Venkateswarlu and Reddy, 1985; Sahu et al., 1994; Diwedi, 2010; Singh, 2010; Kumar and Bhushan, 2012). And also these characteristics were used to know the level of water pollution increasing and/or decreasing by inorganic metals and organic compounds by regulatory authorities as routine checkup but biomonitoring especially morphological changes in algal species as potent tool, few works have been reported in different waterbodies as in situ and/or ex situ conditions (Ahluwalia et al., 1989; Sabeena, and Fatma, 1999; Prygielet al., 1999; Gómez and Licursi, 2003; Cattaneo et al., 2004; Tapia, 2008; Falasco et al., 2009a; Falasco et al., 2009b; Diwedi, 2010; Singh and Chaudhary, 2011; Morin et al., 2012; Rimet, 2012, Pandey et al., 2014).

Generally algae are producers in an aquatic ecosystem and pollutants accumulated in them that may reach to higher trophic level through food chain easily. These species may show tolerant with elevated levels of accumulation of pollutants and also sensitive to pollutants are showing morphological anomalies (Falasco et al., 2009a; Falasco et al., 2009b; Diwedi, 2010; Morin et al., 
2012; Rimet, 2012, Pandey et al., 2014). It was documented that several types of algae species are inhabiting at the bank of river Ganga (Indian Institute of Technology Report, 2012) but no work has been attempted the biomonitoring with special reference to morphological alterations as indicator algae species (Zygnema sp.) at the bank of river Ganga, West Bengal while few works on algae have been reported on river Ganga bank at Indian part and other riverine ecosystem (Rai, 1978; Jindal and Sharma, 2011; Singh and Chaudhary, 2011; Chalotra et al., 2013; Halder, 2015) in relation to sensitive and tolerant species.

The present study aims to know particular types of algae Zygnema sp. inhabited at Ganga river bank and assessment of morphological anomalies as biomonitoring tool for sewage wastewater mixing area compared with non-sewage mixing area at the suburban bank of river Ganga, West Bengal, India.

\section{MATERIALS AND METHODS}

\section{Study area}

The study was carried out at experimental sites, downstream at Khardah (Latitude $=22^{\circ} 43^{\prime} \mathrm{N}$ and Longitude $=88^{\circ} 21^{\prime} \mathrm{E}$ ), as the area exhibits a major sewage water outfall in the river was compared with upstream control site Kalyani (Latitude $=22^{\circ} 59^{\prime} \mathrm{N}$ and Longitude $=88 .^{\circ} 24^{\prime} \mathrm{E}$ ) as no sewage water discharge. Both sites are located in the Ganga river basin in West Bengal, which is meeting at the Bay of Bengal.

\section{Sample collection and morphological study}

The study was carried out in the above mentioned experimental site and at control site during low tide conditions, in the bank of the river Ganga. The study was done in duplicate in one week interval. The study was based on presence and abundance of algae especially Zygnema sp. in relation sewage wastewater discharge area at the bank of Ganga river compared to control area (no sewage discharge area). The test species were collected by hand-picking followed by preservation in glass vial containing 5\% formalin solution. These vials were brought to the laboratory and slides were prepared in iodine solution and mounted in $10 \%$ glycerin followed by the method of Chalotra et al. (2013). The inhabited test species was identified and observed morphological abnormalities such as cell wall (external changes) and chloroplast (internal changes) deformities under brightfield microscope at 20x, 40x and 100x (oil immersion) magnifications (Olympus).

\section{RESULTS}

The present results clearly indicated that Zygnema sp. has showed several external and internal morphological anomalies in the experimental site as sewage discharged and mixing area when compared to control site as non-sewage discharged area. There were two types of deformities observed under brightfield microscope of different magnifications.

The external features as cell wall of Zygnema sp. was observed without any outgrowth alongwith continuous segments in control samples (Fig. 1 and 1a) while in experimental area, the cell wall showed undulating or wavy structure alongwith some thick layering and outgrowth of thread like structure (Fig. 2a, 2b, 2c and 2d). It was also noted that cell wall bend inwardly and outwardly (Fig. 2e). In Fig. 2f, the whole cell between two segments and also many threads like outgrowths from that segment were also dried.

In case of internal abnormal morphology, it was observed that the proximal and distal end of all the segment have pigment loss (Fig. 3a) and different shapes viz. circular, rectangular, oval and amoeboid shapes of nucleus were observed (Fig. 3b). The enlarged view of two types of abnormalities were depicted in Fig. 3c and d. In Fig 3d, the vacuolated nucleus, cell dried in between two segments (Fig. 3e) was also observed. The trilobed nucleus within each segment (Fig. 
3f) and vacuoles were showed in between segments (Fig. 3g). The broom like chloroplasts were observed in distal position of each segment (Fig. 3h).

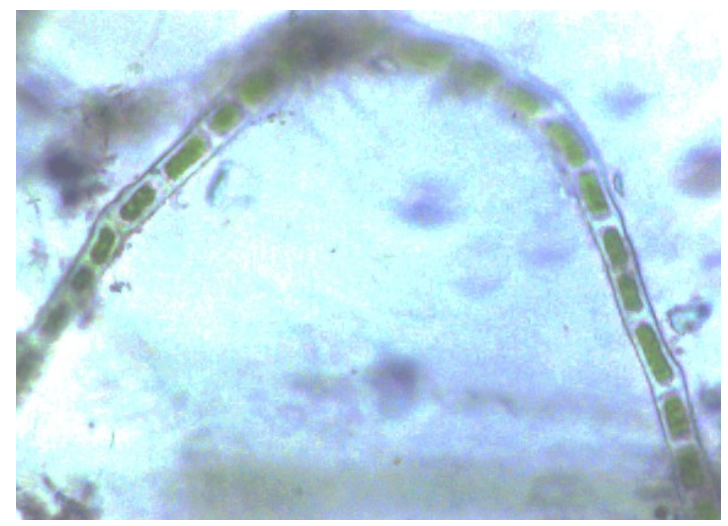

Fig. 1. Normal morphological features in Zygnema sp. (20x)

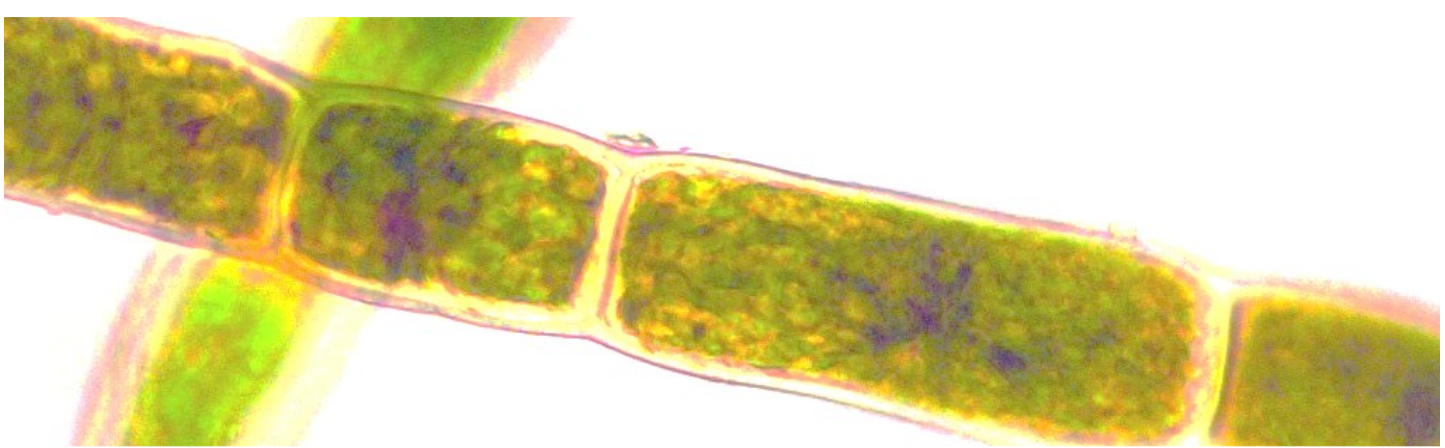

Fig. 1a. Normal morphological feature in Zygnema sp. (100x)

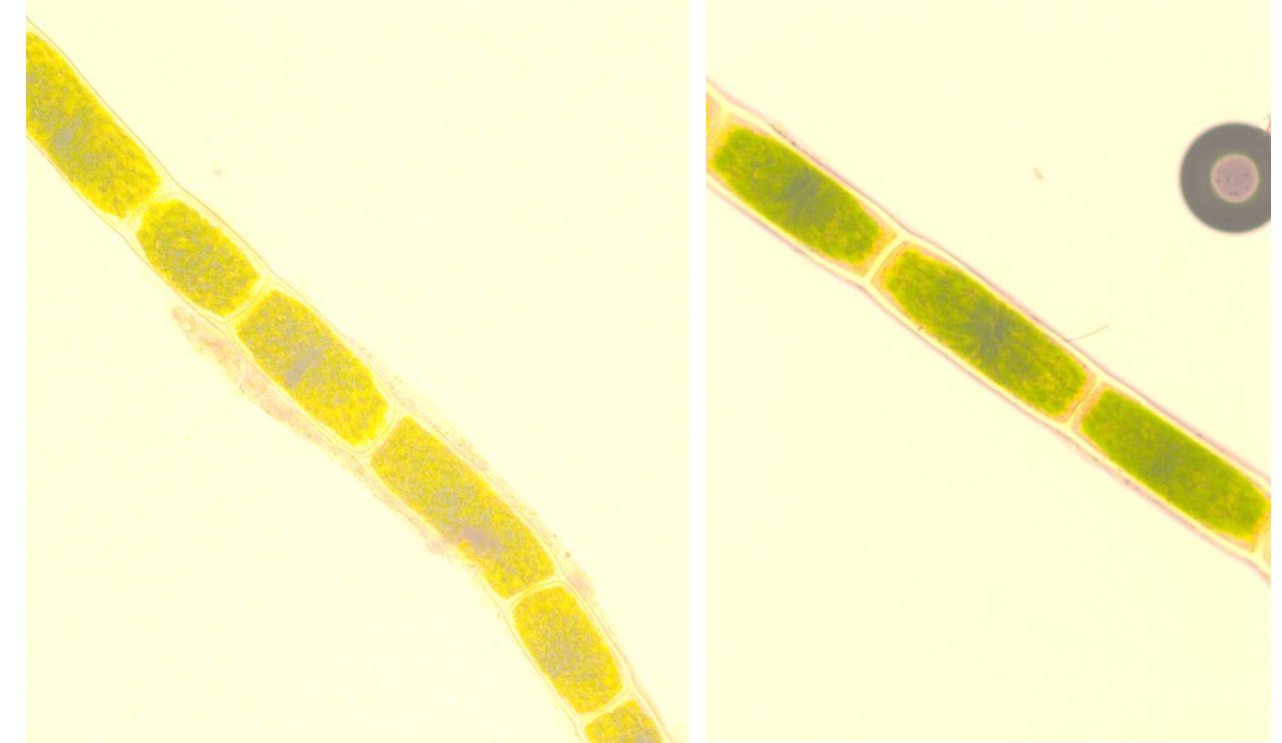

Fig. 2a and b. Different external morphological abnormalities in Zygnema sp. (40x) 
Fig. 2c. External morphological abnormalities in Zygnema sp. (100x)

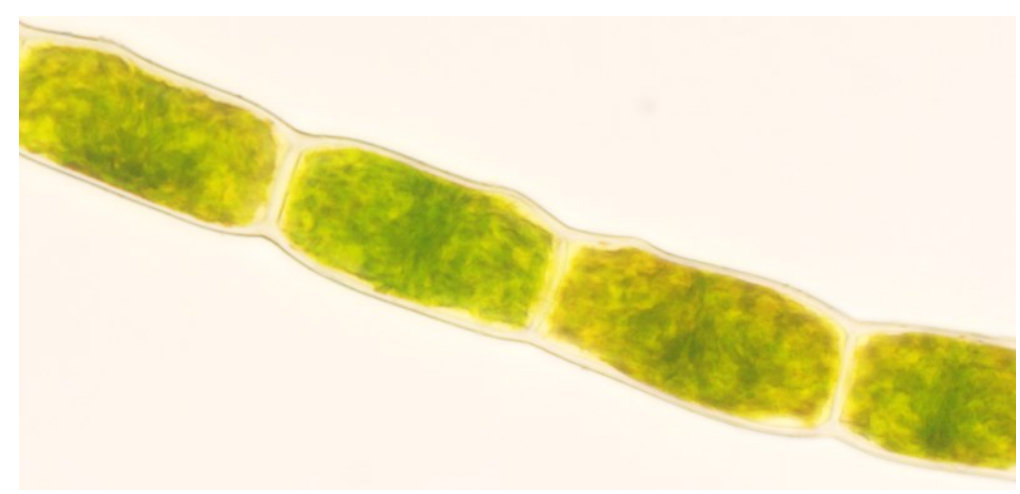

Fig. 2d. External morphological abnormalities in Zygnema sp. (100x)

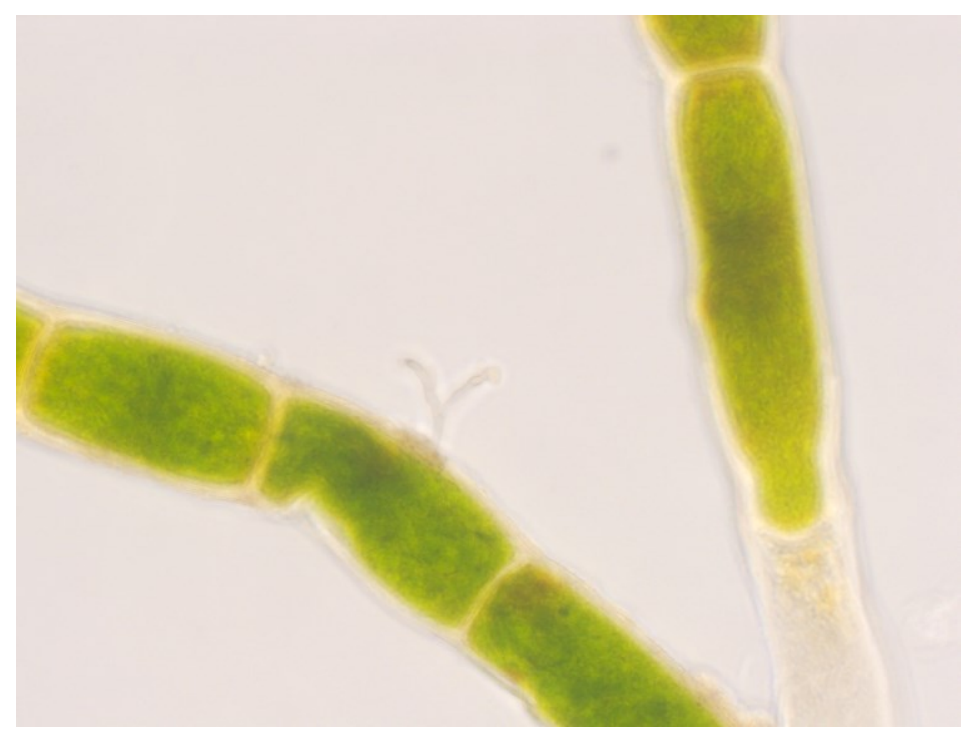

Fig. 2e. Different external morphological abnormalities in Zygnema sp. (40x) 


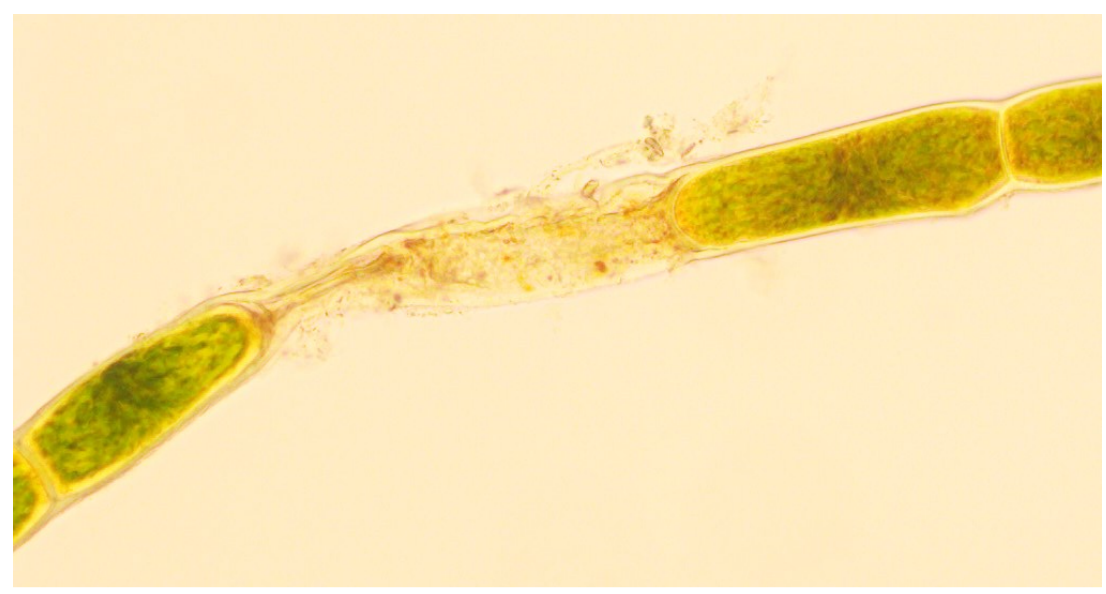

Fig. 2f. External morphological abnormalities in Zygnema sp. (40x)

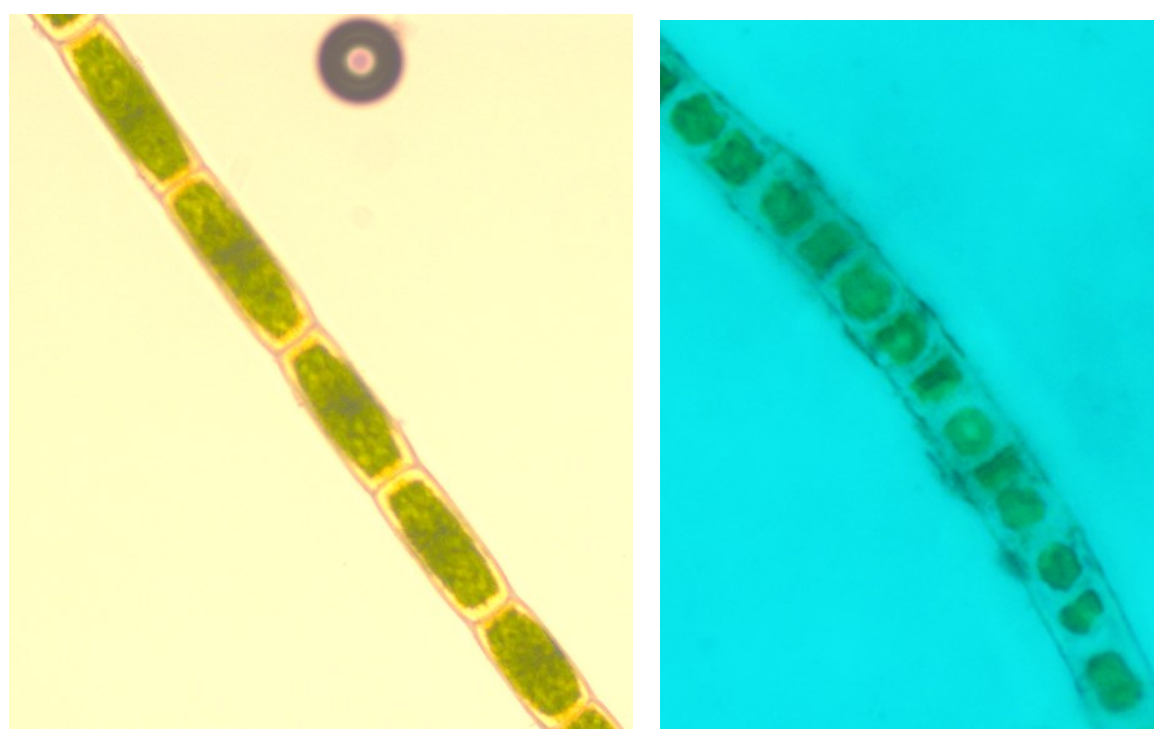

Fig. 3a and b. Different internal morphological abnormalities in Zygnema sp. (40x)
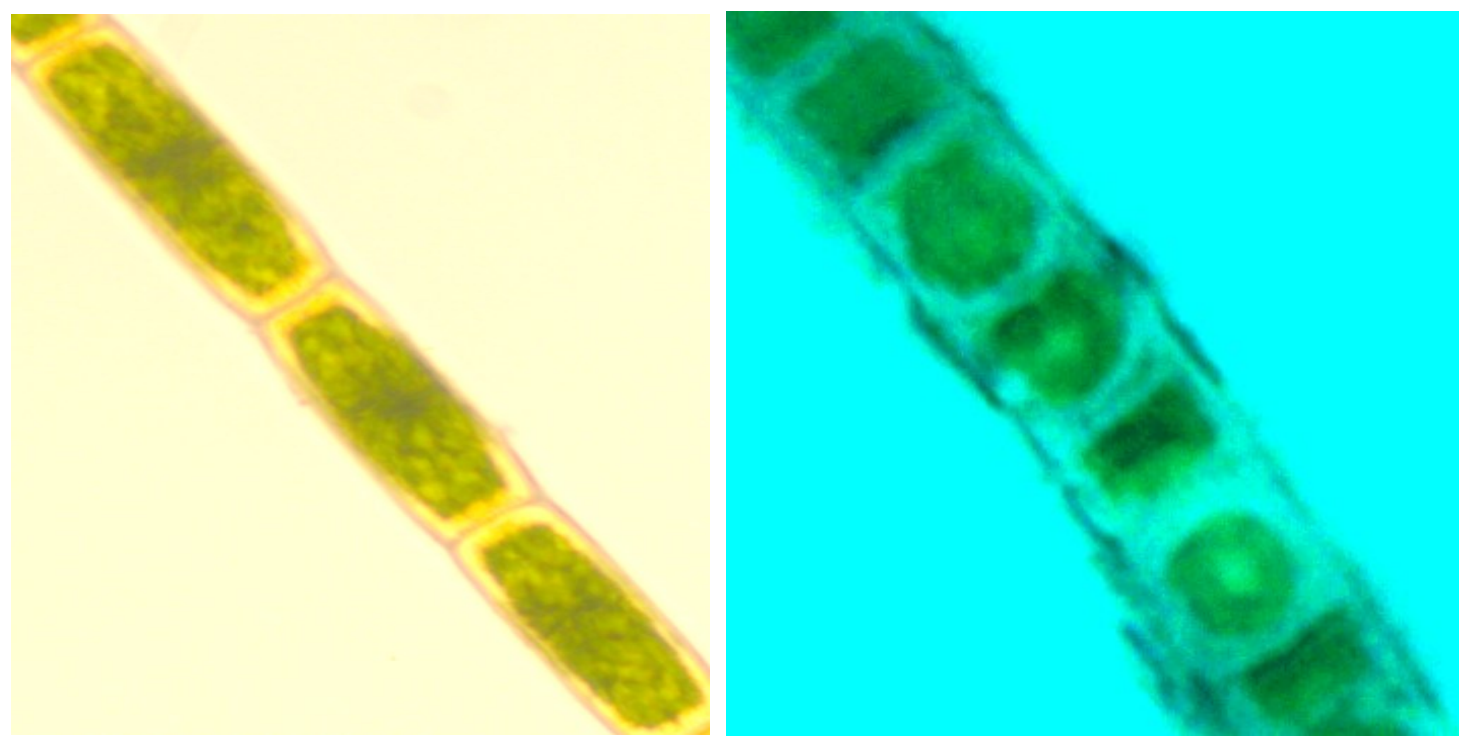

Fig. 3c and d. Different internal morphological abnormalities in Zygnema sp. (100x) 


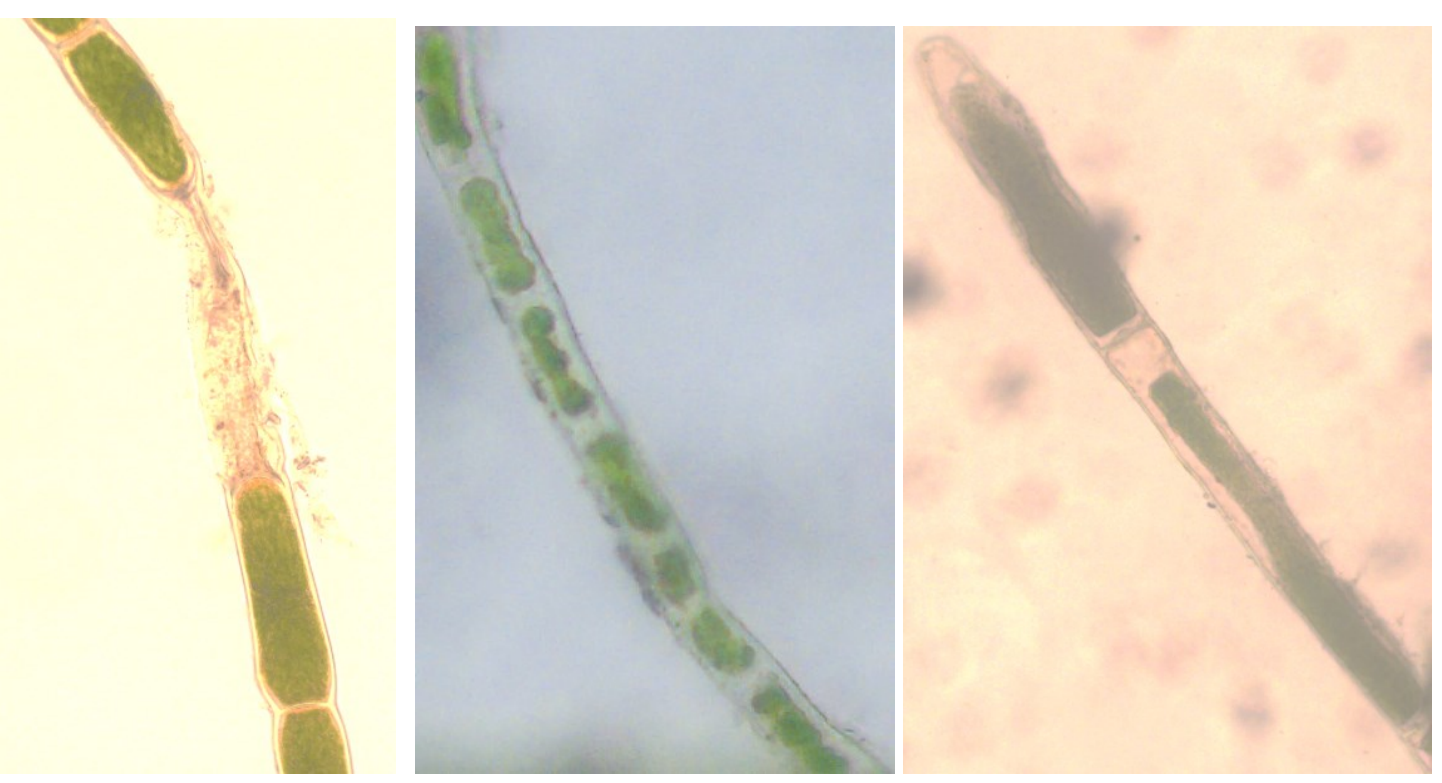

Fig. 3e, f, g. Different internal morphological abonormalities in Zygnema sp. (40x)

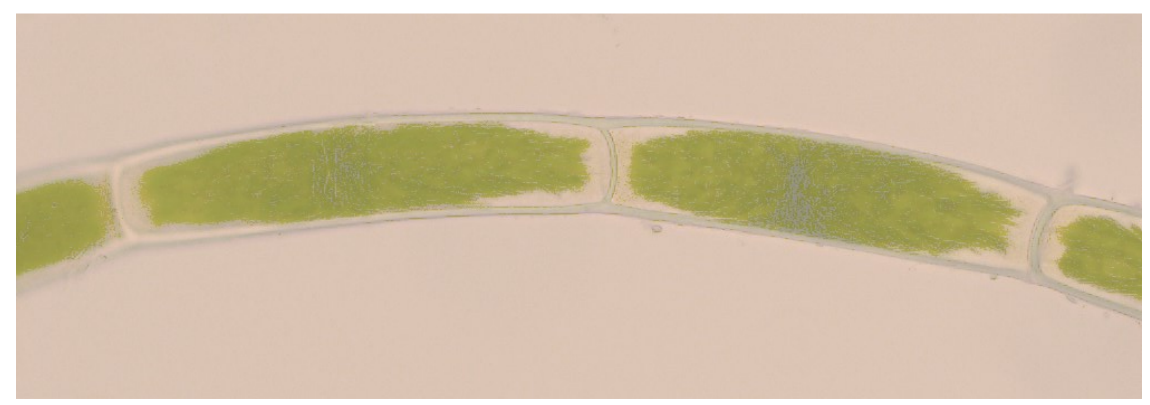

Fig. 3h. Internal morphological abnormalities in Zygnema sp. (100x)

\section{DISCUSSION}

The present study revealed that the abnormal morphological features in algae can be a suitable tool to detect water quality for lentic and lotic ecosystem before studying physico-chemical parameters. The inorganic and organic water pollution monitoring by analysis of physico-chemical parameters of waterbodies is a continuous effort to know water quality criteria by regulatory authorities and recommended different treatment facilities. Less attention has been found on biomonitoring in algal species as potent tool at the bank of river Ganga, West Bengal, scattered biomonitoring works on Ganga river, different parts of India and other rivers have been supported the present research (Rai, 1978; Ahluwalia et al., 1989; Sabeena, and Fatma, 1999; Prygielet al., 1999; Gómez and Licursi, 2003; Cattaneo et al., 2004; Tapia, 2008; Falasco et al., 2009a; Falasco et al., 2009b; Diwedi, 2010; Singh and Chaudhary, 2011; Morin et al., 2012; Rimet, 2012, Pandey et al., 2014) to know sensitive and tolerant indicator algae. Besides these previous studies, it was also known that the test organism has alter their morphological features during winter and spring for the reproduction (Chalotra et al., 2013). This is a preliminary observation and the test species were collected near final sewage mixing area (Khardah) compared to non-sewage mixing area (Kalyani). It is suggesting to know the pollution load by analysis of physico-chemical parameters in the particular area and correlate with the present study of biomonitoring of other sensitive as well as tolerant algae species (Rai, 1978).

Generally Zygnema sp. is survived with stress resistant conditions such as temperature, heat, desiccation etc. and other environmental conditions viz. salt stress, UV irradiation (Pichrtov et al., 2014) and the present study indicated that the test species may be adapted in stress conditions (Rai and Gaur, 2001; Singh and Chaudhary, 2011) because the river water is mixed with pollutants in many parts of India. 
It was documented that several types of algae species are inhabiting at the bank of river Ganga (Indian Institute of Technology Report, 2012) but no work has been attempted the biomonitoring with special reference to morphological alterations as indicator algae species (Zygnema sp.) at the bank of river Ganga designated suburban area of West Bengal. According to Ahluwalia et al. (1989), the growth retardation of green algae Scenedesmus sp. has been documented. It was also reported that heavy metals altered the morphology of algae due to heavy metal pollution and algae can be used as pollution indicator in riverine ecosystem (Pandey et al., 2014, Halder, 2015). Future research may be relevant in relation to physico-chemical properties of water of this particular zone alongwith biomonitoring study at biochemical and gene levels.

\section{CONCLUSION}

The biomonitoring with special reference to know morphological alterations in algae species is a suitable tool for the inorganic, organic and sometimes both pollution load in lotic and lentic ecosystem. It is well supported by many researchers that algae species are suitable indicators of pollutants (Vyasand Kumar, 1968; Rai, 1978; Ahluwalia et al., 1989; Jindal and Sharma, 2011; Halder, 2015). Moreover, it was reported that the water of river Ganga is mixed with pollutants by domestic wastewater, industrial effluent, agricultural runoff etc. in different parts of India (Ahluwalia et al., 1989; Singh and Chaudhary, 2011) and documented alarming load of pollution in West Bengal (Roy et al., 2014). The present preliminary study with Zygnema sp. can be utilized for in situ and ex situ adaptive species for riverine biomonitoring (Vyas and Kumar, 1968; Halder, 2015). Further research may be relevant to know both tolerant and sensitive algae species inhabited at the river Ganga bank alongwith physico-chemical parameters of water. The present work is suggesting that inhabiting and this adaptive algae species can be used for bioremediation of pollutants.

\section{References}

[1] Aggarwal D.K., Gaur S.D., Tiwari I.C., Narayanaswami M.S., Marwali S.M. Indian Journal of Environmental Health 18 (1976) 201-206.

[2] Ahluwalia A.S., Kaur M., Dua S. Indian Journal of Environmental Health 31 (1989) 112-119.

[3] Cattaneo A., Couillard Y., Wunsam S., Courcelles M. Journal of Paleolimnology 32 (2004) $163-175$.

[4] Chalotra P., Gaind M., Anand V.K. International Journal of Science and Knowledge 2 (1) (2013) 14-25.

[5] Diwedi S. World Academy of Science, Engineering and Technology 4 (2010) 11-26.

[6] Falasco E., Bona F., Badino G., Hoffmann L., Ector L. Hydrobiologia 623 (2009a) 1-35.

[7] Falasco E., Bona F., Ginepro M., Hlúbiková Hoffmann L., Ector L. Water SA 35 (2009b) 595605.

[8] Gómez N., Licursi M. Nova Hedwigia 77 (2003) 389-398.

[9] Halder N. Cibtech Journal of Bio-Protocols 4 (1) (2015) 22-26.

[10] Indian Institute of Technology Report. Floral and Faunal Diversity in Lower Ganga, Farakka to Gangasagar, GRB EMP: Ganga River Basin Environment Management Plan. Report Code: 027_GBP_IIT_ENB_DAT_04_Ver_June (2012).

[11] Jindal R. Sharma C. International Journal of Environmental Sciences 2 (2) (2011) 863-872.

[12] Kumar M. Bhushan B. Assessment of water quality of river Ganga at Shukratal in relation to the potability norms. Bionano Frontier, Eco Revolution Colombo - Sri Lanka (2012) pp. 25-29. ISSN 0974-0678. 
[13] Mitra A.K. Indian Journal of Environmental Health 24 (1982) 165-179.

[14] Morin S., Cordonier A., Lavoie I., Arini A., Blanco S., Duong T.T., Tornés E., Bonet B., Corcoll N., Faggiano L., Laviale M., Pérès F., Becares E., Coste M., Feurtet-Mazel A., Fortin C., Guasch H., Sabater S. Consistency in diatom response to metal-contaminated environments. In: Guasch, H., Ginebreda, A., Geiszinger, A. (eds.), Emerging and Priority Pollutants in Rivers. Springer-Verlag, Berlin (2012) pp. 117-146.

[15] Pandey L.K., Kumar D., Yadav A., Rai J., Gaur J.P. Ecological Indicators 36 (2014) 272-279.

[16] Pichrtov M., Hajek T., Elster, J. FEMS Microbiology Ecology 89 (2014) 270-280.

[17] Prygiel J., Coste M., Bukowska J. Review of the major diatom-based techniques for the quality assessment of the rivers - state of the art in Europe. In: Prygiel, J., Whitton, B.A., Bukowska, J. (Eds.), Use of Algae for Biomonitoring Rivers III. Agence de 1_Eau Artois- Picardie, France (1999) pp. 224-238.

[18] Rai L.C. Indian Journal of Fisheries 5 (1) (1978) 1-6.

[19] Rai L.C., Guar J.P. Algal Adaptation to Environmental Stresses. Springer-Verlag; Berlin Heidelberg, New York (2001).

[20] Rimet F. Hydrobiologia 683 (2012) 1-24.

[21] Sabeena S., Fatma T. Phykos 38 (1\&2) (1999) 87-92.

[22] Roy P.K., Ray D., Pal S., Banerjee G., Majumder A., Mazumdar A. World Applied Sciences Journal 29 (5) (2014) 634-640.

[23] Sahu B.K., Rao R.J. Behra S.K. Ecology Environment \& Conservation 1(1-4) (1994) 35-38.

[24] Singh N. International Journal of Energy and Environment 1(5) (2010) 823-32.

[25] Singh A.K., Rai L.C. Biomedical and Environmental Sciences 3 (1990) 397-405.

[26] Singh A.P., Chaudhary B.R. Journal of Algal Biomass Utilization 2 (1) (2011) 21-29.

[27] Tapia P.M. International Journal of Environmental Health 2 (2008) 82-91.

[28] Venkateswarlu V., Manikya Reddy P. Algae as biomonitors in river ecology. Proc. Symp. Biological monitoring of the state of Environment. Indian National Science Academy, New Delhi (1985) pp. 183-189.

[29] Vyas L.N., Kumar H.D. Hydrobiologia 31 (1968) 421-434. 